\title{
Paleoenvironmental evolution of the coastal plain of Southern Brazil: palynological data from a Holocene core in Santa Catarina State
}

\author{
LIDIA A. KUHN ${ }^{1}$, PAULO A. SOUZA ${ }^{1}$, RODRIGO R. CANCELLI ${ }^{1}$, \\ WAGNER G. SILVA ${ }^{1,2}$ and RENATO B. MACEDO ${ }^{1}$ \\ ${ }^{1}$ Programa de Pós-Graduação em Geociências, Universidade Federal do Rio Grande do Sul/UFRGS, \\ Instituto de Geociências, Departamento de Paleontologia e Estratigrafia, Laboratório de Palinologia \\ Marleni Marques Toigo, Av. Bento Gonçalves, 9500, 91540-000 Porto Alegre, RS, Brazil \\ ${ }^{2}$ Instituto Federal de Educação, Ciência e Tecnologia do Rio Grande do Sul/IFRS, Campus \\ Osório, Rua Santos Dumont, 2127, 95520-000 Osório, RS, Brazil
}

Manuscript received on December 20, 2016; accepted for publication on February 7, 2017

\begin{abstract}
This paper presents a paleoenvironmental reconstruction from palynological analyses of a sedimentary core of Holocene age, drilled at municipality of Garopaba (Santa Catarina), Southern Brazil. A total of 46 samples was collected for palynological analyses in the $450 \mathrm{~cm}$-long core PCSC-3, as also three samples for radiocarbon dating and granulometric analyses. The palynological content includes 84 taxa related to pollen grains of angiosperms (38) and gimnosperm (3), spores of pteridophyta (16) and bryophyta (2), spores of fungi (8), algae (3), acritarchs (3), dinoflagellate cysts (2) and microforaminiferal linings (1). Three specimens of acritarchs are described and illustrated in detail. Three palynological phases were defined based on changes in assemblages: Phase I, Phase II and Phase III. The Phase I is characterized as a lagoonal paleoenvironment with marine influence from the beginning of the sedimentation (5390 cal yr BP), based on occurrences of acritarchs, dinoflagellate cysts and microforaminiferal linings. The Phase II (3032 yr BP until $858 \mathrm{cal} \mathrm{yr} \mathrm{BP)} \mathrm{also} \mathrm{is} \mathrm{characterized} \mathrm{by} \mathrm{a} \mathrm{lagoonal} \mathrm{paleoenvironment,} \mathrm{however,} \mathrm{presented}$ decrease in percentage of marine elements and increase in freshwater algae record, suggesting less marine influence in the lagoonal body. In Phase III (last 856 years), underwater sedimentation prevailed, under swamp-like conditions.
\end{abstract}

Key words: coastal plain, environmental evolution, Holocene, palynology, Santa Catarina.

\section{INTRODUCTION}

The paleoclimatic variations and the sea level oscillations modelled the coastal areas worldwide in the Quaternary, resulting in significant sedimentary changes on the Southern Coastal Plain of Brazil. The sedimentary deposits formed during this time

Correspondence to: Lidia Aumond Kuhn

E-mail: lidiaak.lak@gmail.com span comprise coastal plain important records on the evolution of Southern of Brazil, providing data set for local and regional analysis of the geological and vegetational history. In recent years, the Coastal Plain of Santa Catarina has shown an intense human occupation, resulting in negative impacts on the natural scenery, especialy near the coastline (Strohaecker 2008). 
Several palynological studies in Southern and southeastern Brazil based on palynomorph analysis have demonstrated the coastal environmental changes in response to Holocene sea-level variation (de Oliveira et al. 2005). However, little is known about the paleoenvironmental history of Santa Catarina Coastal Plain (e.g., Slompo 1997, Behling and Negrelle 2001, Amaral et al. 2012), when compared to nearby areas, especially Rio Grande do Sul (see summary in Bauermann et al. 2009) and Rio de Janeiro States (e.g., Luz et al. 2006, Freitas and Carvalho 2012, Souza et al. 2016).

Palynological data constitute an important tool for paleoclimatical, paleoecological and paleoenvironmental analysis because microfossil assemblages present high potential of preservation. Microfossils are generaly abundant in pelitic deposits, and are distributed in a wide variety of habits and habitats, within marine and transitional to continental basins. Thus, the record of certain marine palynomorphs and the analysis of their frequency and relative abundance in comparison with continental palynomorphs are commonly used as proxies for the delimitation of transgressive and regressive sea level events. This has been done for Brazilian (e.g., Cordeiro and Lorscheitter 1994, Behling and Negrelle 2001, de Oliveira et al. 2005, Meyer et al. 2005a, b), Southern South American (e.g., Vilanova et al. 2006, Borremei and Quattrocchio 2007, Quattrocchio et al. 2008, Mourelle et al. 2015) and other continents (e.g., de Vernal and Giroux 1991, de Vernal 2009, Mudie et al. 2011, Richards et al. 2014), in most cases integrated with other tools of analysis, such as the sedimentology and geochronological calibration.

This study presents the results of a palynological analysis performed from the $450 \mathrm{~cm}$ long core PCSC-3 collected in the Coastal Plain of Santa Catarina. A paleoenvironmental model is proposed for the last $5390 \mathrm{cal} \mathrm{yr} \mathrm{BP}$, based on the palynological associations, mainly taxa of spore-pollen, algae cysts, dinoflagellate cysts, microforaminiferal linings and acritarchs.

\section{STUDY AREA}

This study was performed on a peat deposit (PCSC3) located in Garopaba (coordinates $28^{\circ} 02^{\prime} 11.95^{\prime} \mathrm{S}$; 48 37'41.73”W), Santa Catarina State, Southern Brazil, about $70 \mathrm{~km}$ from the state capital and ca. $2 \mathrm{~km}$ from the Atlantic Ocean coastline (Figure 1).

The Coastal Plain of Santa Catarina has two main geological units: the Basement (Precambrian, Paleozoic and Mesozoic units) to the west, and the Pelotas and Santos sedimentary marginal basins (Cretaceous to Quaternary) to the east. The municipality of Garopaba is in the onshore portion of the Pelotas Basin. The basement is composed of Precambrian rocks of the Catarinense Shield, and Paleozoic and Mesozoic sedimentary rocks, including Jurassic/Cretaceous magmatic rocks of the Serra Geral Formation (Diehl and Horn Filho 1996) of the Paraná Basin. The marginal sedimentary deposits comprise continental systems, corresponding to colluvial deposits, alluvial and fluvial fans, in the higher portions. The coastal system has the barrier-lagoon system, and comprises Pleistocene and Holocene deposits associated with the relative sea level variations developed during the Quaternary (Horn Filho 2003).

The climate of Santa Catarina State, similar to the entire Southern Brazil, is influenced by the South Atlantic Anticyclone and the Polar Migratory Anticyclone. The South Atlantic Anticyclone produces the tropical warm and humid air masses, which predominate during spring and summer, while the Polar Migratory Anticyclone is more active during the autumn and winter, producing the Atlantic polar mass, which is characterized by low temperatures (Nimer 1990). The climate of Coastal Plain of Santa Catarina is tropical humid (Cfa) in the Köppen classification, with maximum average 
temperature of more than $22^{\circ} \mathrm{C}$, minimum average between -3 and $18^{\circ} \mathrm{C}$, and rains distributed evenly along the year (Alvares et al. 2013).

The Atlantic Forest biome covers the entire Santa Catarina State, and forms fragments of dense ombrophylous forest and a mixed ombrophylous forest (Araucaria forest), integrating the Atlantic Forest. This forest is composed of areas of deciduous forest, steppe (altitude fields) and pioneering formations, such as mangroves and "restingas" (MMA/SBF - Ministério do Meio Ambiente/ Secretaria de Biodiversidade e Florestas 2010). In the most internal portion, the dense ombrophylous forest dominates in Santa Catarina, characterized by an ombrophilous climate with no dry period during the year and average temperatures between $22^{\circ} \mathrm{C}$ and $25^{\circ} \mathrm{C}$ (IBGE - Instituto Brasileiro de Geografia e Estatística 2004). A “restinga" ecosystem lies along the coast, in the river plains and around alluvial depressions (marshes, lakes and lagoons). This vegetation is conditioned by edaphic factors of first occupation character, where the soils are renewed by successive deposition of marine sand (IBGE 2012).
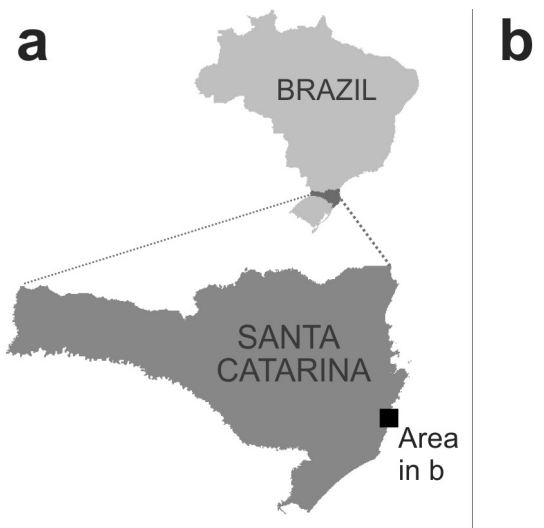

Legend:
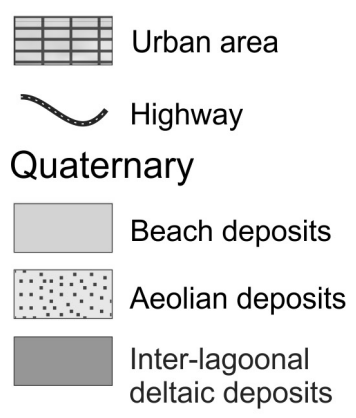

Pre-Quaternary

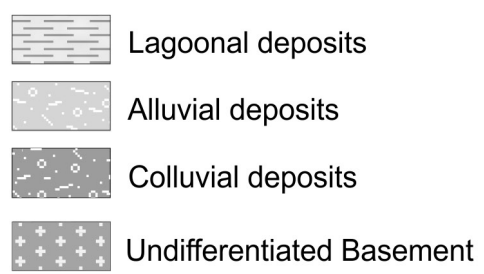

b $\quad 48^{\circ} 39^{\prime} \mathrm{W}$

$48^{\circ} 36^{\prime} \mathrm{W}$

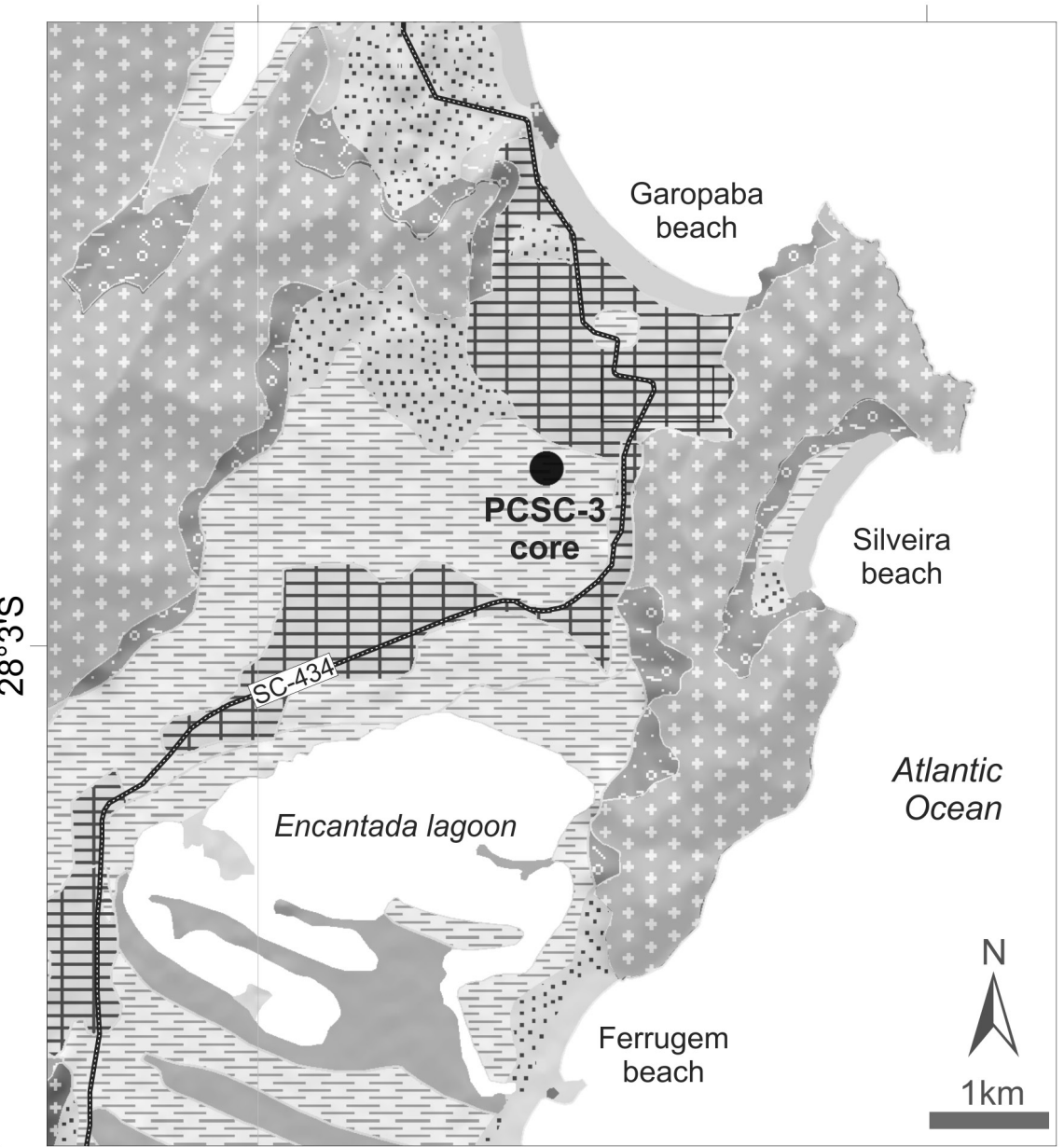

Figure 1 - General location of Santa Catarina in Brazil (a), the PCSC-3 core (Garopaba municipality) (b), including the main Quaternary and pre-Quaternary deposits (modified from Horn Filho et al. 2012). 


\section{MATERIALS AND METHODS}

\section{SAMPLING AND PALYNOLOGICAL PREPARATION}

The $450 \mathrm{~cm}$-long core PCSC-3 was collected using a Russian Peat Borer. The core was wrapped in plastic and aluminum film, taken to the laboratory and stored under refrigeration. All processing techniques were performed in the Laboratório de Palinologia Marleni Marques Toigo, Instituto de Geociências, Universidade Federal do Rio Grande do Sul (LPMMT/IG/UFRGS). Sampling of the core was at $10 \mathrm{~cm}$ spacing, totalling 46 samples of $1 \mathrm{~cm}^{3}$ each. The samples were submitted to the standard techniques of preparation for pollen analyses of Quaternary sediments (Ybert et al. 1992), modified by using sequentially $\mathrm{HF}, \mathrm{HCl}, \mathrm{KOH}$, acetolysis, and followed by filtering through a $250 \mu \mathrm{m}$ mesh sieve. One tablet containing spores of Lycopodium clavatum L. (18.584 \pm 371 spores) was added to each sample to control processing and pollen concentration (Stockmarr 1971). Four permanent slides of each sample were prepared using Entellan, presently housed in the stratigraphical slide collection of the LPPMT/IG/UFRGS under code "MP-P".

\section{GRANULOMETRY AND RADIOCARBON DATING}

Granulometrical analyses were made of 16 samples selected along the core, using the Laser Scattering Particle Size Distribution Analyzer LA-950, of the Centro de Estudos Costeiros e Oceânicos (CECO/IGeo/UFRGS). Radiocarbon dating of three selected samples were done at the CAIS Laboratory of the University of Georgia (USA), using Accelerator Mass Spectrometry (AMS). Calibration of radiocarbon dating used the program CALIB Radiocarbon Calibration version 7.1 (Stuiver et al. 2016), considering the "The Southern Hemisphere SHCal13 radiocarbon calibration curve" (Hogg et al. 2013). Interpolated ages were calculated using linear interpolation on Tilia software version 1.7.16.

\section{PALYNOLOGICAL ANALYSIS}

A minimum of 300 pollen grains were counted for each sample, whenever possible. When not possible, quantitative analysis was finalized after reaching the count of 300 spores of L. clavatum. Levels with less than 300 pollen grains were also considered for the percentage and cluster analyses. The taxonomic determinations of palynomorphs retrieved were performed by comparison with modern equivalents in pollen reference colections ("MP-Pr" slides of the LPMMT/IGeo/UFRGS) and by comparison with specialized literature of Quaternary palynology, mainly those from South America (e.g., Hooghiemstra 1984, Neves and Lorscheitter 1992, Herrera and Urrego 1996, Lorscheitter et al. 1998, Colinvaux et al. 1999, Borel and Gómez 2006, Leal and Lorscheitter 2006, Macedo et al. 2009, Cancelli et al. 2012).

Percentage diagram and cluster analyses were constructed using the Tilia versions 1.7.16 (Grimm 2011). The low concentration of pollen grains did not allow the plot of percentages of "pollen sum". Thus, a total sum of palynomorphs $(100 \%)$ was calculated for each level, including pollen grains, spores of bryophyta and pteridophyta, fungi, algae, acritarchs, dinoflagellate cysts and microforaminiferal linings. The calculation of the percentage of each group was performed using the total sum of palynomorphs. The results of analyses of palynomorphs are presented in percentage diagrams.

\section{RESULTS}

\section{SEDIMENTOLOGY AND RADIOCARBON DATA}

The studied core consists of unconsolited sediments composed by intercalations of fine silt and fine sand layers, of variable thickness (Figure 2), rich in organic matter. Between 450 and $275 \mathrm{~cm}$, the 
sediments are predominatly grey, and between 275 and $125 \mathrm{~cm}$ they are dark. Completely decomposed organic material occurs from the base to $125 \mathrm{~cm}$ of depth, while between 125 and $40 \mathrm{~cm}$, sediments are dark brown with a mixture of decomposed organic matter and roots. The uppermost $40 \mathrm{~cm}$ are composed of dark brown sediments with abundant plant debris, mainly modern roots.

Three radiocarbon dates from the $450 \mathrm{~cm}$-long core yield chronological control. The results of the AMS radiocarbon dating are presented in Table I, showing that the deposition of the studied core occurred entirely in the late middle Holocene. The lowermost level $(430 \mathrm{~cm})$ has the age $5390 \mathrm{cal} \mathrm{yr}$ $\mathrm{BP}$, while the sample at $360 \mathrm{~cm}$ depth was dated at $3756 \mathrm{cal}$ yr BP. The uppermost level ( $80 \mathrm{~cm}$ depth) revealed an age of $858 \mathrm{cal}$ yr BP. Figure 2 shows the detailed grain size variation and the location of samples extracted for palynological analyses and radicarbon dating.

\section{FOSSIL POLLEN RECORD}

Among the 46 samples, only three (samples 1, 2 and 43) were considered barren in palynomorphs, and thus discarded for analysis. A total of 84 distinct palynomorphs was identified from the other samples, including taxa of angiosperms (38), gimnosperms (3), spores of pteridophytes (8),

TABLE I

Radiocarbonic and calibrated ages of selected samples from the PCSC-3 core.

\begin{tabular}{|c|c|c|c|}
\hline Sample number* & $\begin{array}{l}\text { Depth } \\
\text { (cm) }\end{array}$ & $\begin{array}{c}\text { Age } \\
\left({ }^{14} \mathrm{C} \text { yr BP }\right)\end{array}$ & $\begin{array}{c}\text { Calibrated } \\
\text { age } \\
\text { (cal yr BP) } \\
\text { probability } \\
\text { avarage }\end{array}$ \\
\hline $\begin{array}{c}\text { UGAMS\#26651 } \\
(38)\end{array}$ & 80 & $1010 \pm 26$ & 858 \\
\hline $\begin{array}{l}\text { UGAMS\#26650 } \\
\text { (10) }\end{array}$ & 360 & $3520 \pm 25$ & 3756 \\
\hline $\begin{array}{l}\text { UGAMS\#26539r } \\
\text { (3) }\end{array}$ & 430 & $4650 \pm 25$ & 5390 \\
\hline
\end{tabular}

*Serial number of CAIS Laboratory of University of Georgia and our number control (in parenthesis).

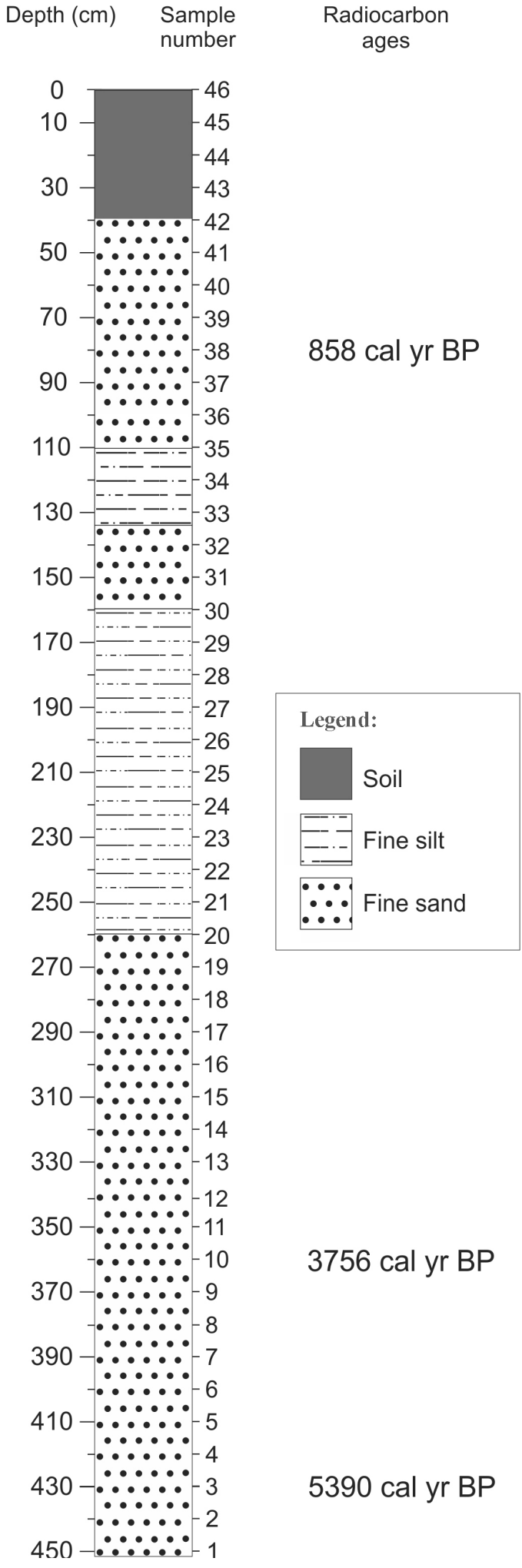

Figure 2 - Schematic sedimentar column of the PCSC3 core showing the grain size variation, location of samples extracted for palynological analyses. 
bryophytes (2) and fungi (8), algae (3), acritarchs (3), dinoflagellate cysts (2), microforaminiferal linings (1), as well as 16 unknown types of spores and pollen grains (Table II).

Along the core, the palynological diagrams show the distribution of palynomorphs, grouped according to their ecological affinities (habit or habitat). Three palynological phases are defined (Figure 3) from changes in the palynomorph assemblages: Phase I, Phase II and Phase III. These are described in sequence in ascending stratigraphical order. The main criteria for the establishment of the phases are the relationship between terrestrial, aquatic and marine elements (Figure 4). Three taxa are referred to as open nomenclature among the acritarchs as described and illustrated herein (Figure 4a-e) due to their importance for paleoenvironmental interpretations and comparisons with other palynological assemblages.

Phase I (5390 cal yr BP- 3135 yr BP)

This phase is the basal portion of the core, including samples 3 to 16 (430 to $295 \mathrm{~cm}$ of depth). Aquatic macrophytes are present $(0.6 \%)$ with only one taxa (Myriophyllum aquaticum). The pollen record of herbs represents 0.4 to $16.5 \%$ of the total palynomorphs, highlighting Amaranthus/ Chenopodiaceae, Poaceae, Oxalidaceae Asteraceae subf. Cichorioideae, Asteraceae subf. Asteroideae. Trees and shrubs have a varied occurrence (0.229.7\%), especially Ilex, Arecaceae, Alchornea and Myrtaceae, followed by Sebastiania, Celtis, Proteaceae, Trema micrantha, Mimosa serie Lepidotae, including species with only one occurrence: Allophylus, Dodonaea viscosa, Faramea, Lithraea and Matayba. Regional (1.3\%) and extraregional flora $(0.4 \%)$ are present at this phase, with occurrence of Araucaria angustifolia (Bertol.) Kuntze, Ephedra tweediana C.A. Mey., Alnus Mill. and Nothofagus Blume. Spores of mosses have low frequency $(<1.3 \%)$; spores of fern are more frequent (0.5-21.1\%), comprising Polypodiaceae, Blechnum, Cyathea and Dicksonia. A high percentage of algae is observed (between 8.3-95.5\%), especially dominated by Botryococcus. Fungi spores are also abundant in this phase (2.1$51.9 \%$ ). Marine palynomorphs are represented by microforaminiferal linings, dinoflagellate cysts (Operculodinium sp. and Spiniferites sp.) and acritarchs (Micrhystridium sp., Acritarch sp. 1 and Acritarch sp. 2) which are well recorded, especially in samples 8 and 12 (380 and $340 \mathrm{~cm}$ of depth), reaching up to $18 \%$.

Phase II (3032 yr BP- 858 cal yr BP)

This phase comprises 21 samples (295 to $85 \mathrm{~cm}$ of depth). Percentages of pollen from aquatic plants are also low, with the occurrence of only one species (Myriophyllum). This phase is characterized by decrease of herb pollen $(0.8-11.5 \%)$ and by a relative increase of pollen sum of forest taxa $(0.5$ 46.1\%), when compared to the Phase I. Herbs pollen are represented mainly by Poaceae, Asteraceae subf. Asteroideae, Asteraceae subf. Cichorioideae, Amaranthus/Chenopodiaceae, as well as other less frequent taxa, such as Apiaceae, Cyperaceae, Gomphrena, Oxalidaceae and others with only one occurrence: Cuphea, Rubiaceae and Utricularia. Tree and shrub pollen are mainly recorded by Ilex, Myrtaceae, Arecaceae, Sebastiania, Alchornea and other less representative taxa, such as Celtis, Lithraea, Mimosa serie Lepidoteae, Myrsine, T. micrantha and others with first appearance in the core: Ericaceae, Mimosoideae, Podocarpus and Sapium. Regional (A. angustifolia and E. tweediana) and extraregional (Alnus) flora taxa are also present, reaching up to 0.9 and $0.2 \%$, respectively. Epiphyte pollen are recorded, despite the low occurrence $(<4.2 \%)$. Although the record of spore mosses increases in the section $(1.5 \%)$, they have a irrelevant account. Spores of pteridophytes 
reach up to $1.3-14 \%$. Polypodiaceae, Blechnum, Cyathea and Dicksonia were also recorded and other ones occurred for the first time in the core (Huperzia and Pteridaceae). The high percentage of algae (12.7-94.4\%) and fungi (0.7-46.5\%) persists in this phase. Marine elements decrease $(<3.3 \%)$, represented by all taxa recorded in the Phase I.

Phase III (858 cal yr BP until the present)

This phase was recognized from eight samples between $85 \mathrm{~cm}$ of depth to the top of the core. The aquatic macrophytes have only one taxa in the register (Polygonum). This phase is marked by the increase of herb pollen (5.9-22.7\%), represented by Asteraceae subf. Asteroideae, Asteraceae subf. Cichorioideae, Poaceae other less frequent taxa, such as Apiaceae, Cyperaceae, Amaranthus/
Chenopodiaceae, Gomphrena and Malvaceae. Tree and shrub pollen are also recorded in high percentages (reaching $44.8 \%$ in the sample from the top of the core), mainly represented by Ilex, Ericaceae, Myrtaceae, Arecaceae and Myrsine. Other forest taxa, such as Drimys brasiliensis, Alchornea, Mimosoideae, Podocarpus, Sebastiania, Proteaceae and Sapium also occur in lower proportions. Epiphytic taxa reach 26.9\%, with the occurrence of Cucurbitaceae. Moss spores increase $(<9.1 \%)$, with the presence of Sphagnum and Phaeoceros, as well as fern spores (1.2-26.9\%), mainly represented by Polypodiaceae and Blechnum; Dicksonia, Osmunda and Cyathea. Algae taxa show a marked decrease at this phase $(<15.8 \%)$, while fungi spores present high percentage (13.5-71\%); marine palynomorphs were not detected.

TABLE II

Palynomorphs identified in the PCSC-3 core according to their habitat and habit.

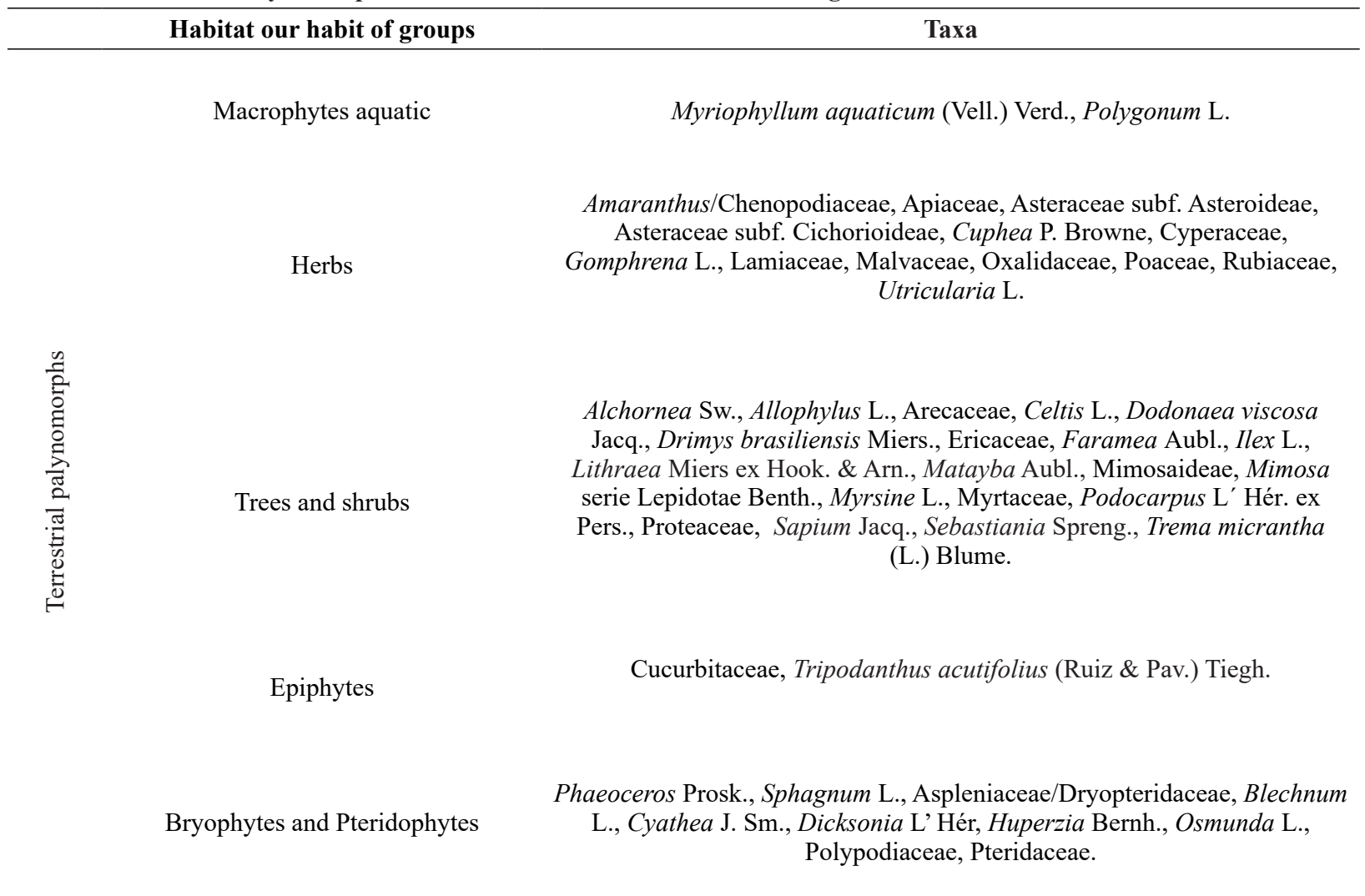


TABLE II (continuation)

\begin{tabular}{|c|c|c|}
\hline & Habitat our habit of groups & Taxa \\
\hline 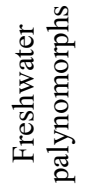 & Algae & $\begin{array}{l}\text { Botryococcus Kütz., Pseudoschizaea rubina Rossignol ex Christopher, } \\
\text { Spirogyra Link. }\end{array}$ \\
\hline 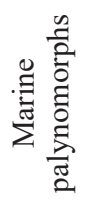 & $\begin{array}{l}\text { Acritarchs, dinoflagellate cysts and } \\
\text { microforaminiferal linings }\end{array}$ & $\begin{array}{l}\text { Operculodinium Wall, 1967, Spiniferites Mantell, 1850, Micrhystridium } \\
\text { (Deflandre) emend. Serjeant \& Stancliffe 1994, Acritarch sp. 1, Acritarch } \\
\text { sp. 2, Microforaminiferal linings. }\end{array}$ \\
\hline
\end{tabular}

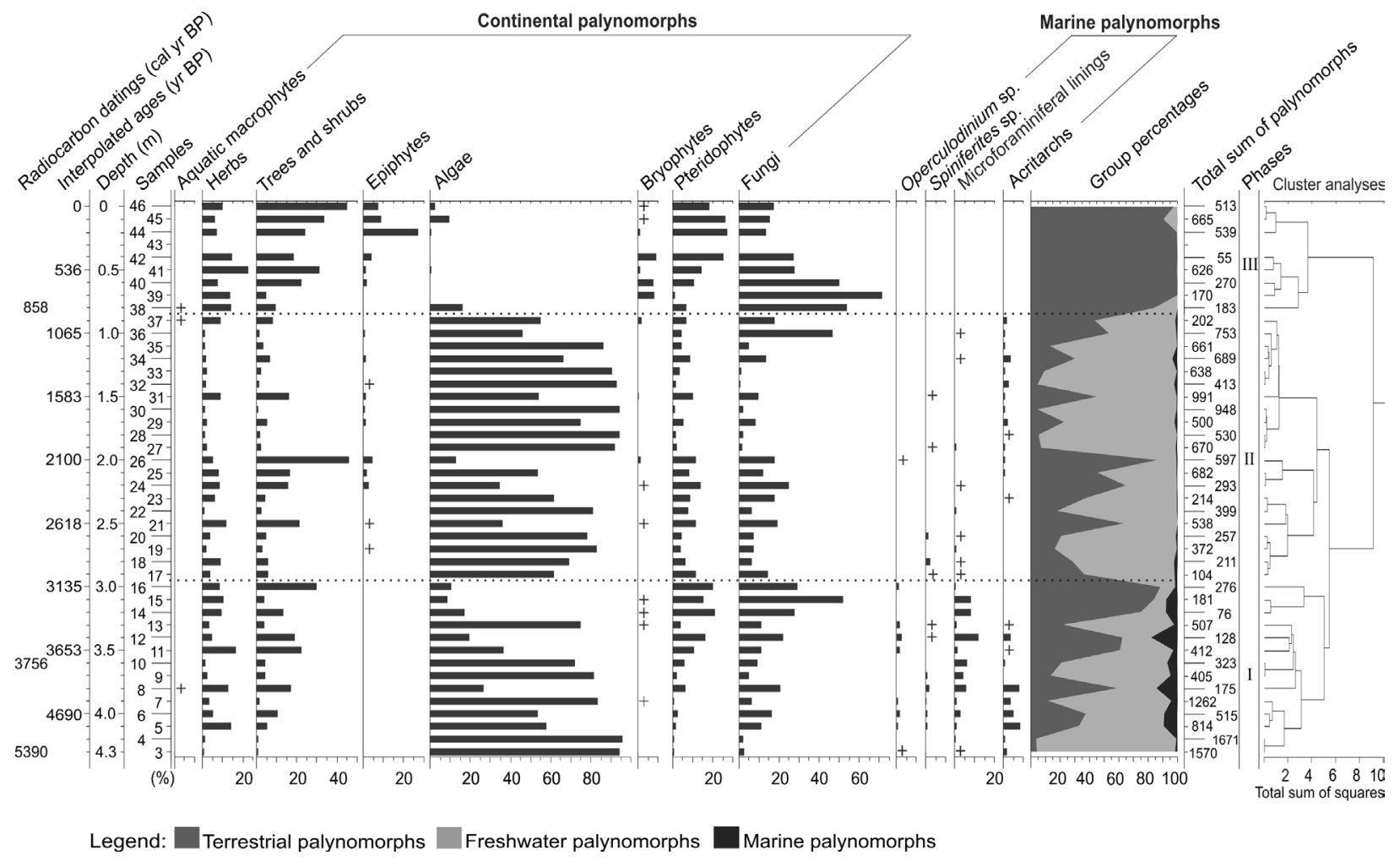

Figure 3 - Percentage diagram of the palynomorphs grouped according to their ecological affinities (habit or habitat) from the PCSC-3 core, as well as the identified phases and cluster analyses. The symbol $(+)$ represents an occurrence of palynomorphs.

\section{SYSTEMATIC PALYNOLOGY}

Group ACRITARCHA Evitt, 1963

Genera Micrhystridium (Deflandre) emend.

Serjeant \& Stancliffe 1994

\section{Micrhystridium sp.}

(Figure 4a and 4b)
Description (20 specimens measured): Hyaline and spheroidal palynomorphs; overall diameter: $10-14 \mu \mathrm{m}$, exine thickness: $1 \mu \mathrm{m}$, spines: $1 \mu \mathrm{m}$ of height. Some specimens show small openings in the form of a straight breach.

Comparisons: Cancelli et al. (2012) identified specimes assigned to the genera Michrystridium 


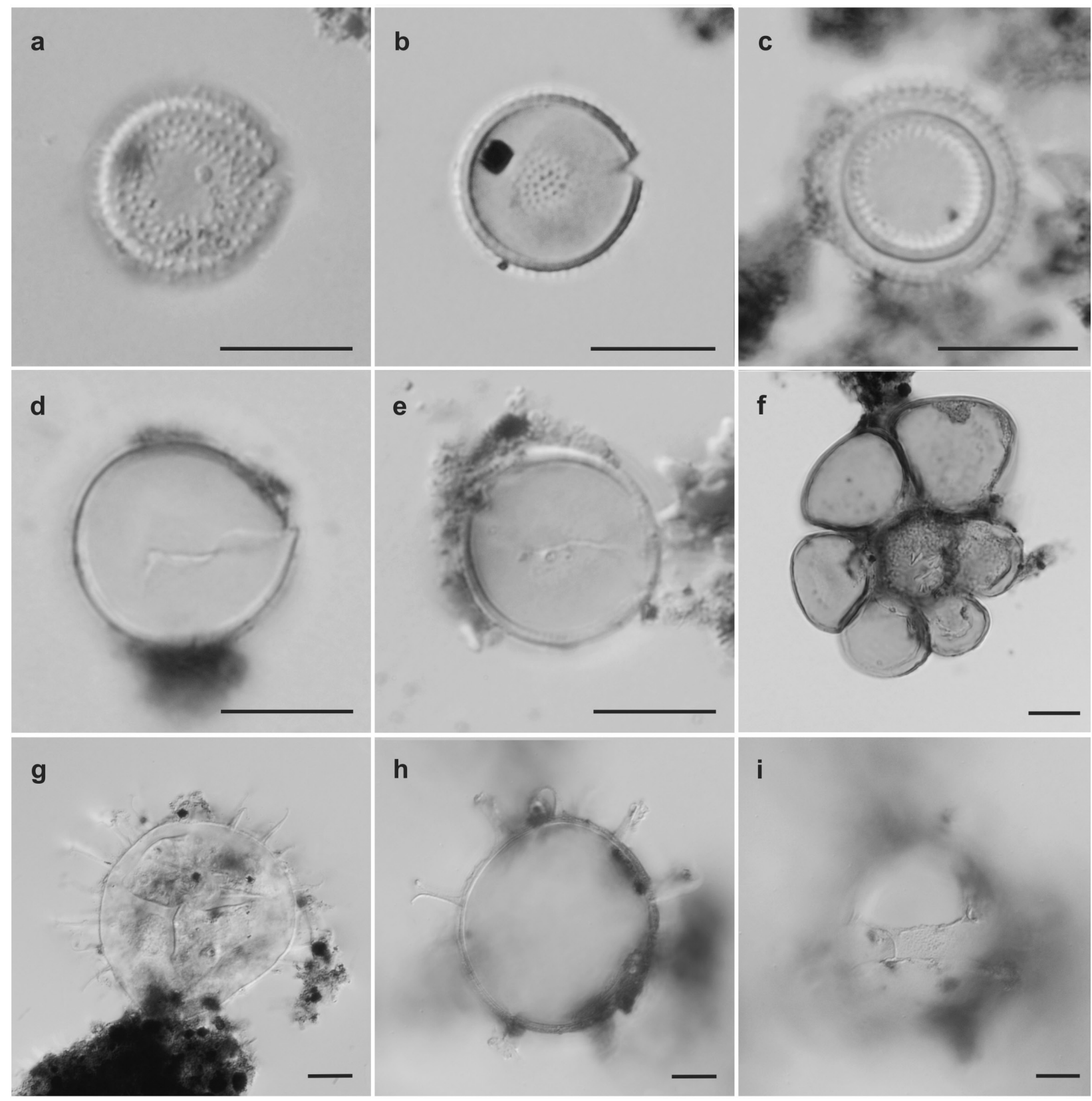

Figure 4 - Photomicrographs of marine palynomorphs retrieved from the PCSC-3 core. a-b: Micrhystridium sp. (Slide MPP-9981, England Finder coordinate N41-1); (a: high focus, b: intermediate focus); c: Acritarch sp. 1 (MPP-9937, T51-2); d-e: Acritarch sp. 2 (MPP-9981, U39-3 and D44-1); f: Microforaminiferal linings (MPP-9976, U43); g: Operculodinium sp. (MPP-9972, F65); h-i: Spiniferites sp. (MPP-9982, P38-4); (h: intermediate focus and i: high focus). Scale $=10 \mu \mathrm{m}$.

from Holocene sediments of the Southern coast of Santa Catarina, described with the same shape and ornamentation; however, those taxa show slightly larger size (ca. $18 \mu \mathrm{m}$ of diameter). In Rio Grande do Sul, Neves and Bauermann (2003) described certain specimens of Michrystridium as having globular cysts, hyaline and with tiny spines, but the specimens also present differences in the range of overal diameter (18 to $22 \mu \mathrm{m}$ ). Several studies from the Coastal Plain of Rio Grande do Sul record the genera Micrhystridium from Holocene deposits. However, the available descriptions are 
illustrated in some cases but are insufficient for a deeper comparison (e.g., Cordeiro and Lorscheitter 1994, Medeanic et al. 2001, 2007, 2009, 2010, Medeanic 2006a, b, Neves and Bauermann 2001, Weschenfelder et al. 2008).

The genus Michrystridium has been also found in Holocene sediments in Uruguay (Mourelle et al. 2015) and in Argentina (Borel and Gómez 2006, Borel 2007). Borel and Gómez (2006) described a taxon with the same characteristics as found in our material, named as Michrystridium sp., with 0.5-1 $\mu \mathrm{m}$ of exine thickness, spines of $1-2 \mu \mathrm{m}$ of height and 9-19 $\mu \mathrm{m}$ of overal diameter, as well as openings in tear forms in some species.

\section{Acritarch sp. 1}

(Figure 4c)

Description (six specimens measured): Hyaline, thick walled and spheroidal palynomorphs; overal diameter: 12-15 $\mu \mathrm{m}$, exine thickness: 1.5-2 $\mu \mathrm{m}$, spine: $1 \mu \mathrm{m}$ of height.

Comparisons: Medeanic et al. (2010) identified similar specimens to this species from a Holocene deposit in Rio Grande do Sul, named as Michrystridium. However, a more precise analysis is limited due to the absence of description and the poor quality of the photomicrograph.

Acritarch sp. 2

(Figure 4d and 4e)

Description (20 specimens measured): Hyaline, psilate ornamentation and spheroidal palynomorphs; overall diameter: $10-14 \mu \mathrm{m}$, exine thickness: $1 \mu \mathrm{m}$, spine: $1 \mu \mathrm{m}$ of height. Some specimens show small openings in the form of straight tear.

Comparisons: Specimens similar to Acritarch sp. 2 were recorded by Borel and Gómez (2006) and Borel (2007) from Holocene sediments in Argentina. These similar specimens were identified as Acritarch sp. F, described as spheroidal, thick- walled palynomorphs, psilate, with some species showing tear-shaped openings. According to Borel and Gómez (2006), in their life cycle, some species (Pyramimonas) of freshwater algae or tidal environments form small benthic spores with morphology similar to these acritarchs.

\section{DISCUSSION}

The results obtained from the palynological analysis of the core indicate paleoenvironmental changes during the late Middle Holocene to the Recent, represented by three phases. Phase I (5390 cal yr $\mathrm{BP}-3135 \mathrm{yr} \mathrm{BP}$ ) is marked by the presence of marine palynomorphs, suggesting the proximity to marine water. High percentages of freshwater algae reveal an input of freshwater in the environment.

In Phase I, the algae of genera Botryococcus dominate the palynological association (Figure 3 ). Percentage of spores of fungi vary throughout this phase. Pteridophytes spores show a relative increase towards the top of the phase. Pollen grains (herbs, shrubs and trees) have low percentage. Aquatic macrophytes have isolated occurrences. In this phase, the marine palynomorphs reach the highest percentage in relation to the subsequent phases.

High percentage of algae of genera Botryococcus indicate an input of freshwater in the depositional site. The occurrence of spores of pteridophytes reinforces the interpretation of the presence of fresh water, because these elements depend on water for their reproductive cycle. The low abundance of pollen grains suggests a long distance between the source area and depositional site.

The occurrence of the acritarchs (Michrystridium sp., Acritarch sp. 1 and Acritarch sp. 2), dinoflagellate cysts (Operculodinium sp. and Spniferites sp.), as well as microforaminiferal linings, indicates the influence of marine water. The Acritarch sp. 2, similar to specimens of the 
Sphaeromorphitae subgroup, and the specimes assigned to the genera Michrystridium are characteristic of shallow coastal water associations (Montenari and Leppig 2003, Félix and Souza 2012). The genera of dinoflagellate cysts Spiniferites and Operculodinium correspond to gonyaulacoids forms, which have a cosmopolitan character, being recorded in a wide range of environments, from internal neritic to open ocean, revealing tolerance to a large range of salinity, luminosity, nutrients and temperature (de Vernal et al. 2001, Marret and Zonneveld 2003). Microforaminiferal linings are abundant in estuarine marshes of variable salinity (Batten 1996).

The high percentage of Botryococcus added whit the presence of marine elements indicates that the sedimentation environment was lagoonal. The occurrence of spores of fungi throughout this phase can be explained by the erosion of the river banks that transported organic matter to the lagoonal body, in agreement with Muller (1959) taking into account Recent sediments from Orinoco river. The frequent herbs taxa, mainly represented by Amaranthus/Chenopodiaceae and Poaceae, can be related to dry sandy soils (including halophytes taxa), as also interpreted by Lorscheitter (2003) from Holocene samples of Serra Velha and Guaíba. The beginning of sedimentation of Phase I coincides with the last sea-level maximum documented for the Brazilian coast between 5000 and 5800 cal yr BP (Angulo et al. 2006). Two samples in the middle of this phase (380 and $340 \mathrm{~cm}$ of depth), close to 3756 cal yr BP, presented higher percentage of marine palynomorphs, these data suggest that the depositional site had marine influence. Others works in Santa Catarina State demonstrated which between $3000 \mathrm{yr}$ BP and $3800 \mathrm{yr}$ BP the sea level was above the present sea level (Suguio et al. 1985, Angulo et al. 1999).

Marine influence was also observed in Volta Velha, northern Santa Catarina, due to the presence of microforaminiferal linings between 6720 to
4330 yr BP (Behling and Negrelli 2001). Amaral et al. (2012) also registered marine influence in the Jaguaruna region, South-central portion of the Coastal Plain of Santa Catarina, between approximately 5000 to $2580 \mathrm{yr} \mathrm{BP}$, based on diatoms and isotopes. Several palynological studies (e.g., Cordeiro and Lorscheitter 1994, Lorscheitter and Dillenburg 1998, Medeanic et al. 2001, Meyer et al. 2005a) recorded the transgressive event (at approximately $5000 \mathrm{yr}$ BP) in the Coastal Plain of Rio Grande do Sul by means of palynological indicators, as dinoflagellate cysts (Spiniferites and Operculodinium), microforaminiferal linings and acritarchs (Michrystridium).

In studies of Holocene sediments in Argentina (Bahía Blanca and Arroyo La Ballanera) and Uruguay (Río de La Plata northeastern coast), marine input was identified from associations of acritarchs with the dinoflagellate cysts Spiniferites and Operculodinium (Borel and Gómez 2006, Borel 2007, Mourelle et al. 2015). Borel and Gómez (2006) and Borel et al. (2007) identified, in addition to Michrystridium sp., an acritarch named Acritarch sp. F. This form is very similar to Acritarch sp. 2 (Figure 4d and 4e), described herein, because it has psilate, spheroidal and hyaline wall, of small size.

In the Phase II, Botryococcus continues to dominate the palynological association, with a more homogeneous distribution. Spores of pteridophytes and fungi show a small decline in their percentages. Pollen grains (herbs, shrubs and trees) continue to have low representation in the palynological association; epiphytes make their first appearance at this phase. Marine palynomorphs decrease compared to the previous phase.

The continuous high percentages of algae of genera Botryococcus indicate that input of fresh water was not interrupted between Phase I and Phase II. The presence of taxa that are waterdependent for their reproductive cycle, spores of pteridophytes and fungi, suggests the presence of 
fresh water in the environment. The low abundance of pollen grains indicates that the vegetation was not close to the depositional site. However, the first appearance of epiphytes (little expression) indicates the presence of forest fragments developed in adjacent areas. The record of marine elements indicates marine water influence. However, the decrease of these elements in relation to Phase I suggests a reduction in the saline water supply.

The high percentage of Botryococcus added to the presence of marine elements indicates that the sedimentation environment was still a lagoonal body. Nevertheless, the low occurrence of marine palynomorphs, with the dominance of acritarchs in the assemblage (with a few specific occurrences of dinoflagellate cysts and microforaminiferal linings), reveals that the connection to the sea was already closed, limiting the seawater input. The decrease of Amaranthus/Chenopodiaceae throughout this phase may reflect the desalination of the soil contiguous to the body of water. Predominance of silt layers indicates a decrease in the energy of the sedimentary environment, corresponding to diminishing marine influence in the lagoonal body. The Phase II is characterized by a transitional paleoenvironment between the Phase I and Phase III.

Phase III corresponds to the last 858 cal yr BP, when algae abruptly decrease and fungi and arboral taxa increase. The drastic decline of algae indicates a depletion in the water column in the depositional site and the absence of marine palynomorphs reveals the end of seawater input.

The high percentage of fungi in the first samples of this phase indicates the beginning of soil development, since the abundance of fungal fragments is indicative of aerobic biodegradation of plant remains (Sebag et al. 2006). Dominance of pollen of herbs and spores of bryophytes (Sphagnum and Phaeoceros) indicates the beginning of vegetation colonization. Both spores of bryophytes and fungi at the lower portion of this phase reflect wet conditions.

The progressive increase of pteridophytes, epiphytes and arboreal taxa (Arecaceae, Ericaceae, Ilex, Myrsine and Myrtaceae), added to the appearance of new taxa (Drimys brasiliensis), reveals the beginning of the development of the Atlantic Forest in the site. However, low richness of the arboreal taxa can be related to the early stage of evolution of this forest in the site.

The lowering and stabilization of relative sea level led to the desalination of the coastal plain lands. These ancient coastal lagoonal and fluvial plains were gradually colonised by the Atlantic Forest. The forest development after coastal regression was also identified in other palynological studies in the Santa Catarina (Behling and Negrelli 2001, Amaral et al. 2012) and Rio Grande do Sul coastal plains (Cordeiro and Lorscheitter 1994, Neves and Lorscheitter 1992, Meyer et al. 2005a, b, Medeanic 2006a, Macedo et al. 2007, Medeanic et al. 2009).

\section{CONCLUSIONS}

The palynological analyses of the $450 \mathrm{~cm}$-long core PCSC-3 in Santa Catarina State (Garopaba) led to the recognition of three phases from $5390 \mathrm{cal}$ yr BP (late Middle Holocene) to close to modern days. These phases are characterized by the presence and the relative frequency of marine (dinoflagellates, acritarchs and microforaminiferal linings), freshwater (Botryococcus) versus continental palynomorphs (spore-pollen taxa, fungi).

Records of marine and freshwater elements indicate that during Phase I and the Phase II the environment comprised a lagoonal body. Phase I reveals higher marine influence, while Phase II presents decrease of percentage of marine elements and increase of freshwater algae record, suggesting less marine influence into the lagoonal body. Phase III is marked by the closing of the connection of the 
lagoon with the sea, with prevalence of subaerial sedimentation, under swamp-like conditions, by means of the vegetation colonization in the locality for the last $856 \mathrm{yr}$ BP. Our conclusions are in agreement with other paleoenvironmental reconstrutions for the sea level oscilations of certain portions of the coastal plain of Brazil, in particular to the Santa Catarina State.

\section{ACKNOWLEDGMENTS}

The authors thank Léo A. Hartmann for contributing with comments during the writing of the article, and Eduardo Barboza for making possible the particle size analysis. This contribution was performed with support grants from the Conselho Nacional de Desenvolvimento Científico e Tecnológico (CNPq proc. 132260/2015-8, 454804/2014-8) and Fundação de Amparo à Pesquisa do Estado do Rio Grande do Sul (FAPERGS proc. APG1012119). The authors also thank reviewers for manuscript revision and suggestions.

\section{REFERENCES}

ALVARES CA, STAPE JL, SENTELHAS PC, GONÇALVES JLM AND SPAROVEK G. 2013. Köppen's climate classification map for Brazil. Meteorol Z 22(6): 711-728

AMARAL PGC, FONSECA PCG, SYLVESTRE F AND PESSENDA LCR. 2012. Paleoenvironmental reconstruction of a Late Quaternary lagoon system in Southern Brazil (Jaguaruna region, Santa Catarina State) based on multi-proxy analysis. J Quaternary Sci 27: 181191.

ANGULO RJ, GIANNINI PCF, SUGUIO K AND PESSENDA LCR. 1999. The relative sea-level changes in the last 5500 years Southern Brazil (Laguna-Imbituba region, Santa Catarina State) based on vermetid ${ }^{14} \mathrm{C}$ ages. Mar Geol 159: 327-339.

ANGULO RJ, GUILHERME CL AND SOUZA MC. 2006. A critical review of mid- to late-Holocene sea-level fluctuations on the eastern Brazilian coastline. Quaternary Sci Rev 25: 486-506.

BATTEN DJ. 1996. Palynofacies and palaeoenvironmental interpretation. In: Jansonius J and McGregor DC (Eds), Palynology: Principles and Applications, Dallas: Am Assoc Strat Palynol 3: 1011-1064.
BAUERMANN SG, BEHLING H AND MACEDO RB. 2009. Biomas e evolução da paisagem no Rio Grande do Sul com base em paleopalinologia. In: Ribeiro AM, Bauermann SG and Scherer CS (Eds), Quaternário do Rio Grande do Sul: Integrando Conhecimentos. Porto Alegre: Monografias da Sociedade Brasileira de Paleontologia, $\mathrm{p}$. 81-93.

BEHLING H AND NEGRELLE RRB. 2001. Tropical rain forest and climate dynamics of the Atlantic lowland, Southern Brazil, during the Late Quaternary. Quaternary Res 56: 383-389.

BOREL CM. 2007. Algas no silíceas y acritarcos de depósitos costeiros holocenos em el Arroyo La Ballenera, Buenos Aires, Argentina. Ameghiniana 44(2): 359-366.

BOREL CM AND GÓMEZ EA. 2006. Palinología del Holoceno del Canal del Medio, estuario de Bahía Blanca, Buenos Aires, Argentina. Ameghiniana 43(2): 399-412.

BORREMEI AM AND QUATTROCCHIO M. 2007. Holocene sea-level change inferred from palynological data in the Beagle Channel, Southern Tierra del Fuego, Argentina. Ameghiniana 44(1): 161-171.

CANCELLI RR, SOUZA PA AND NEVES PCP. 2012. Grãos de pólen de angiospermas do Holoceno (7908 \pm 30 anos AP-atual) da Planície Costeira sul-catarinense, Brasil. Acta Bot Bras 26(4): 866-885.

COLINVAUX P, DE OLIVEIRA PE AND MORENO JE. 1999. Amazon Pollen Manual and Atlas. Amsterdam: Harwood Academic Publishers, 332 p.

CORDEIRO SH AND LORSCHEITTER ML. 1994. Palynology of Lagoa dos Patos sediments, Rio Grande do Sul, Brazil. J Paleolimnol 10: 35-42.

DE OLIVEIRA PE ET AL. 2005. Paleovegetação e paleoclimas do Quaternário do Brasil. In: Souza CRG, Suguio K, Oliveira MAS and de Oliveira PE (Eds), Quaternário do Brasil. Ribeirão Preto: Holos, p. 52-74.

DE VERNAL A. 2009. Marine palynology and its use for studying nearshore environments. IOP Conf. Series: Earth and Environmental Science 5. IOP Publishing, From Deep-sea to Coastal Zones: Methods and Techniques for Studying Paleoenvironments.

DE VERNAL A AND GIROUX L. 1991. Distribution of organic walled microfossils in recent sedimets from the estuary and Gulf of St. Lawrance: some aspects of the organic matter fluxes. In: Therriault JC (Ed), The Gulf os St. Lawrence: small ocean or big estuary? Can Spec Publ Fish Aquat Sci 113: 189-199.

DE VERNAL ET AL. 2001. Dinoflagellate cyst assemblages as traces of sea-surface conditions in the northern North Atlantic, Arctic and sub-Artic seas: the new ' $n=677$ ' data base and its application for quantitative palaeoceanographic reconstruction. J Quaternary Sci 16(7): 681-698.

DIEHL LF AND HORN FILHO NO. 1996. Compartimentação geológico-geomorfológica da zona 
litorânea e planície costeira do estado de Santa Catarina. Notas Técnicas 9: 39-50.

FÉLIX C AND SOUZA PA. 2012. Acritarcos (Grupo Acritarcha Eviit 1963): conceitos gerais, aplicações e importância na análise estratigráfica do intervalo Pennsilvaniano e Permiano da Bacia do Paraná. Rev Inst Geol 33(1): 71-88.

FREITAS AG AND CARVALHO MA. 2012. Análise morfológica e inferências ecológicas de grãos de pólen e esporos (últimos 8.000 anos) da lagoa da Ferradura, Armação dos Búzios, RJ. Brasil. Rev Bras Pleontol 15(3): 300-318.

GRIMM EC. 2011. Tilia version 1.7.16 (Computer Software). Illinois State Museum, Research and Collections Center, Springfield, USA.

HERRERA LF AND URREGO LE. 1996. Atlas de polen de plantas útiles y cultivadas de la Amazonia Colombiana. Estudios em La Amazonia Colombiana. Bogotá: Tropenbos, $462 \mathrm{p}$.

HOGG AG ET AL. 2013. SHCal13 Southern Hemisphere calibration, 0-50,000 years cal BP. Radiocarbon 55(4): 1889-1903.

HOOGHIEMSTRA H. 1984. Vegetational and climatic history of the High Plain of Bogotá, Colombia: A continuous Record of the Last 3.5 Million Years. In: Hammen TVD (Ed), The Quaternary of Colombia, Vaduz: J CRAMER 10: 368.

HORN FILHO NH. 2003. Setorização da Província Costeira de Santa Catarina em base aos aspectos geológicos, geomorfológicos e geográficos. Geosul 18(35): 71-98.

HORN FILHO NO ET AL. 2012. Mapa geológico da planície costeira das folhas Paulo Lopes (SG-22-Z-D-V-4) e Imbituba (SH-22-X-B-II-2), Santa Catarina, Brasil. In: Horn Filho NO (Ed), Atlas geológico da planície costeira do Estado de Santa Catarina em base ao estudo dos depósitos quaternários. Série mapas IBGE - Mapa $n^{\circ} 7$, Escala 1:100.000.

IBGE - INSTITUTO BRASILEIRO DE GEOGRAFIA E ESTATÍSTICA. 2004. Mapa da Vegetação Brasileira (escala 1:5 000 000). Rio de Janeiro, MPOG. Diretoria de Geociências, $3^{\mathbf{a}}$ ed.

IBGE - INSTITUTO BRASILEIRO DE GEOGRAFIA E ESTATÍSTICA. 2012. Manual Técnico da Vegetação Brasileira. Rio de Janeiro, MPOG. Diretoria de Geociências, 271 p.

LEAL MG AND LORSCHEITTER ML. 2006. Pólen, esporos e demais palinomorfos de sedimentos holocênicos de uma floresta paludosa, Encosta Inferior do Nordeste, Rio Grande do Sul, Brasil. Iheringia Ser Bot 61(1-2): 1347.

LORSCHEITTER ML. 2003. Contribution to the Holocene history of Atlantic rainforest in the Rio Grande do Sul
State, Southern Brazil. Rev Mus Argent Cienc Nat 5(2): 261-271.

LORSCHEITTER ML, ASHRAF AR, BUENO RM AND MOSBRUGGER V. 1998. Pteridophyte spores of Rio Grande do Sul flora, Brazil. Part I. Palaeontographica 246: $1-113$.

LORSCHEITTER ML AND DILLENBURG SR. 1998. Holocene paleoenvironments of the northern coastal plain of Rio Grande do Sul, Brazil, reconstructed from palynology of Tramandaí lagoon sediments. Quat S Am Antarct Penins 11: 73-97.

LUZ CFP, BARTH OM AND SILVA CG. 2006. Dinâmica temporal na lagoa do Campelo, região norte do Estado do Rio de Janeiro baseada em estudos palinológicos. Rev Bras Paleontol 9(1): 127-136.

MACEDO RB, CANCELLI RR, BAUERMANN SG, BORDIGNON SAL AND NEVES PCP. 2007. Palinologia de níveis do Holoceno da Planície Costeira do Rio Grande do Sul (Localidade de Passinhos), Brasil. Gaea 3: 68-74.

MACEDO RB, SOUZA PA AND BAUERMANN SG. 2009. Catálogo de pólens, esporos e demais palinomorfos em sedimentos holocênicos de Santo Antônio da Patrulha, Rio Grande do Sul, Brasil. Iheringia Ser Bot 62(2): 43-78.

MARRET F AND ZONNEVELD KAF. 2003. Atlas of modern organic-walled dinoflagellate cyst distribution. Rev Palaeobot Palyno 125(1): 1-200.

MEDEANIC S. 2006a. Freswater algal palynomorph records from Holocene deposits in the coastal plain Rio Grande do Sul, Brazil. Rev Palaeobot Palynol 141: 83-101.

MEDEANIC S. 2006b. The palynomorphs from surface sediments of intertidal marshes in the estuarine part of the Patos lagoon. Iheringia Ser Botanica 61(1-2): 49-62.

MEDEANIC S, CORRÊA ICS AND WESCHENFELDER J. 2007. Palinomorfos nos Sedimentos do Fundo da Laguna dos Patos-RS: Aplicação nas Reconstruções Paleoambientais. Gravel 5: 89-102.

MEDEANIC S, DILLENBURG SR AND TOLDO JR EE. 2001. Novos dados palinológicos da transgressão marinha pós-glacial em sedimentos da Laguna dos Patos, RS, Brasil. Geociências 6: 64-76.

MEDEANIC S, HIRATA F AND DILLENBURG SR. 2010. Algal Palynomorphs Response to Environmental Changes in Tramandaí Lagoon, Southern Brazil, and Climatic Oscillations in the 20th Century. J Coastal Res 26(4): 726735.

MEDEANIC S, TORGAN LC, CLEROT LCP AND SANTOS CB. 2009. Holocene Marine Transgression in the Coastal Plain of Rio Grande do Sul, Brazil: Palynomorph and diatom evidence. J Coastal Res 25(1): 224-233.

MEYER KEB, MENDONÇA FILHO JG, ASHRAF AR, SOUZA PA AND REICHHART K. 2005a. Análise de palinofácies em sedimentos holocênicos da Lagoa dos 
Quadros, Planície Costeira do Rio Grande do Sul, Brasil. Rev Bras Paleontol 8(1): 57-72.

MEYER KEB, REICHHART K, ASHRAF AR, MARQUES-TOIGO M AND MOSBRUGGER V. 2005b. Holocene Evolution of Itapeva lake, Rio Grande do Sul, Brazil: Palynomorphs and Corg, N, S Records. J S Am Earth Sci 19(2): 181-192.

MMA/SBF - MINISTÉRIO DO MEIO AMBIENTE/ SECRETARIA DE BIODIVERSIDADE E FLORESTAS. 2010. Mata Atlântica: patrimônio nacional dos brasileiros. In: Campanili M and Schaffer WB (Eds), Biodiversidade 34, Brasília, 408 p.

MONTENARI M AND LEPPIG U. 2003. The Acritarcha: their classification morphology, ultrastructure and palaeoecological/palaeogeographical distribution. Paläontologische Zeitschrift 77: 173-194.

MOURELlE D, PRIETO AR, PÉREZ L, GÁRCIARODRÍGUEZ F AND BOREL CM. 2015. Mid and late Holocene multiproxy analysis of environmental changes linked to sea-level fluctuation and climate variability of the Río de la Plata estuary. Palaeogeogr Palaeoclimatol Palaeoecol 421: 75-88.

MUDIE PJ, LEROY SAG, MARRET F, GERASIMENKO NP, KHOLEIF SEA, SAPELKO T AND FILIPOVAMARINOVA M. 2011. Nonpollen palynomorphs: indicators of salinity and environmental change in the Caspian-Black Sea-Mediterranean corridor. In: Buynevich IV, Yanko-Hombach V, Gilbert AS and Martin RE (Eds), Geology and Geoarchaeology of the Black Sea Region: Beyond the Flood Hypothesis: Geological Society of America Special Paper 473, p. 89-115.

MULLER J. 1959. Palynology of Recent Orinoco Delta and shelf sediments. Micropaleont 5: 1-32.

NEVES PCP AND BAUERMANN SG. 2001. Feições de uma mata de restinga em Capão do Leão, Planície Costeira Sul, Rio Grande do Sul, Brasil. Pesq Bot 51: 73-86.

NEVES PCP AND BAUERMANN SG. 2003. Catálogo palinológico de coberturas quaternárias no estado do Rio Grande do Sul (Guaíba e Capão do Leão), Brasil. Descrições taxonômicas - Parte I: Fungos, Algas, Palinomorfos outros e fragmentos de invertebrados. Pesq Bot 53: 121-149.

NEVES PCP AND LORSCHEITTER ML. 1992. Palinologia de sedimentos de uma mata tropical paludosa em Terra de Areia, Planície Costeira Norte, Rio Grande do Sul, Brasil. Descrições taxonômicas, parte I: fungos, algas, briófitos, pteridófitos, palinomorfos outros e fragmentos de invertebrados. Acta Geol Leopold 15: 83-114.

NIMER E. 1990. Clima. In: Geografia do Brasil. Região Sul. Rio de Janeiro: IBGE, p. 151-187.

QUATTROCCHIO ME, BORROMEI, AM, DESCHAMPS CM, GRILL SC AND ZAVALA CA. 2008. Landscape evolution and climate changes in the Late Pleistocene-
Holocene, Southern Pampa (Argentina): Evidence from palynology, mammals and sedimentology. Quatern Int 181: $123-138$.

RICHARDS K, BOLICKHOAVKAYA NS, HOOGENDOORN RM, KROONENBERG SB, LEROY SAG AND ATHERSUCH J. 2014. Reconstructions of deltaic environments from Holocene palynological records in the Volga delta, northern Caspian Sea. Holocene 24(10): 1226-1252.

SEBAG D, COPARD Y, DI-GIOVANNI C, DURAND A, LAIGNEL B, OGIER S AND LALLIER-VERGÀS E. 2006. Palynofacies as useful tool to study origins and transfers of particulate organic matter in recent terrestrial environments: synopsis and prospects. Earth Sci Rev 79: 241-259

SLOMPO CTJ. 1997. Estudo palinológico dos sedimentos do mangue de Itacorumbi, Ilha de Santa Catarina, SC, Brasil. Bol Paranaense Geocienc 45: 67-79.

SOUZA TCS, CARVALHO MA, DIAS FF, FERREIRA B, FREITAS AS AND CASTRO WA. 2016. Analysis of Particulate Organic Matter in Holocene Sediments of Coastal Plain from Pero Beach, Cabo Frio, Rio de Janeiro, Brazil. Journal of Sedimentary Environments 1(2): 249-260.

STOCKMARR J. 1971. Tablets with spores used in absolute pollen analysis. Pollen Spores 13: 615-621.

STROHAECKER TM. 2008. Dinâmica populacional. In: Zamboni A and Nicolodi JL (Eds), Macrodiagnóstico da Zona Costeira e Marinha do Brasil, Brasília: MMA, p. 5973.

STUIVER M, REIMER PJ AND REIMER RW. 2016. CALIB 7.1 [WWW program]. Belfast: 14CHRONO Centre, Queen's University Belfast, accessed November $30,2016$.

SUGUIO K, MARTIN L, BITTENCOURT ACSP, DOMINGUEZ JML, FLEXOR JM AND AZEVEDO AEG. 1985. Flutuações do nível relativo do mar durante o Quaternário Superior ao longo do litoral brasileiro e suas implicações na sedimentação costeira. Rev Bras Geocien 15(4): 273-286.

VILANOVA I, PRIETO AR AND ESPINOSA M. 2006. Palaeoenvironmental evolution and sea-level fluctuations along the southeastern Pampa glasslands coast of Argentina during the Holocene. J Quaternary Sc 21(3): 227-242.

WESCHENFELDER J, MEDEANIC S, CORRÊA ICS AND ALIOTTA S. 2008. Holocene Paleoinlet of the Bojuru Region, Lagoa dos Patos, Southern Brazil. J Coastal Res 24(1): 99-109.

YBERT JP, SALGADO-LABOURIAU ML, BARTH OM, LORSCHEITTER ML, BARROS MA, CHAVES SAM, LUZ CFP, RIBEIRO M, SCHEEL R AND VICENTINI KF. 1992. Sugestões para padronização da metodologia empregada em estudos palinológicos do Quaternário. Rev Inst Geol 3: 47-49. 